\title{
IMPLEMENTASI PENARIKAN ROYALTI BAGI PELAKU USAHA KOMERSIAL KARAOKE BERDASARKAN UNDANG-UNDANG NOMOR 28 TAHUN 2014 TENTANG HAK CIPTA
}

Oleh:

\author{
Duwi Aprianti ${ }^{1}$
}

\begin{abstract}
Withdrawal Royalties are the utilization of the economic rights of a work related to the receipt by the creator or the copyright holder. Copyright is a creature created by the creator in a tangible form by not reducing restrictions in accordance with the provisions of the legislation. Copyright applies in all areas of life one of which is the art of music. Songs that have been registered must get Royalties if they are to be used for commercial purposes, the only other who often violates is a commercial karaoke business in royalty payments. The method used in this study is the empirical law whose purpose gives a description of the provisions in the effort to withdraw royalties for commercial business Karaoke.
\end{abstract}

Keywords: copyright, royalty, song, commercial karaoke, karaoke business

\begin{abstract}
Abstrak
Penarikan Royalti adalah pemanfaatan atas hak ekonomi suatu ciptaan yang terkait diterimanya oleh pencipta atau pemegang hak cipta. Hak cipta adalah suatu ciptaan yang dibuat oleh pencipta dalam bentuk nyata dengan tidak mengurangi pembatasan sesuai dengan ketentuan peraturan perundang-undangan. Hak Cipta berlaku di segala bidang kehidupan salah satunya yaitu seni musik. Lagu yang sudah didaftarkan haruslah mendapatkan Royalti apabila akan digunakan untuk kepentingan komersial, salah satunya yang sering melanggar adalah pelaku usaha komersial karaoke dalam pembayaran royalti. Metode yang digunakan dalam penelitian ini adalah hukum empiris yang tujuannya memberikan gambaran yang mengenai ketentuan dalam upaya penarikan royalti bagi pelaku usaha komersial Karaoke.
\end{abstract}

Kata kunci : Hak Cipta, Royalti, Lagu, Komersial Karaoke, Bisnis Karaoke 


\section{PENDAHULUAN}

Indonesia sebagai negara seribu kepulauan yang memiliki keanekaragaman seni dan budaya yang begitu luas dan kaya dengan keanekaragaman etnik, suku, bangsa, dan agama. Kekayaan seni dan budaya itulah yang merupakan potensi nasional yang harus dilindungi. Karya intelektual dari kekayaan seni dan budaya itulah yang dapat dan perlu dilindungi oleh Undang-Undang. Karena kekayaan seni dan budaya yang dilindungi ini dapat meningkatkan kesejahteraan yang tidak hanya bagi penciptanya tetapi juga bagi bangsa dan negara. Dan dapat dimanfaatkan juga untuk meningkatkan kemampuan di bidang perdagangan dan industri yang melibatkan para penciptanya. ${ }^{2}$ Indonesia merupakan negara yang kaya atas Kekayaan Intelektual, dimana perlindungannya diberikan dalam bentuk Hak Kekayaan Intelektual yang diartikan sebagai hak atas kepemilikan karya-karyayanglebihdarikemampuan intelektualitas manusia, misalnya dalam hak cipta melindungi karya ciptaan di bidang seni dalam bentuk ekspresi. Ekspresi itu adalah bentuk tulisan seperti lirik lagu, artikel, puisi, dan buku. Tujuan dari melindungi yaitu untuk perlindungan terhadap namanya plagiat atau penjiplakan oleh orang lain. ${ }^{3}$

2 Ermansyah Djaja, 2009, Hukum Kekayaan Intelektual, Sinar Grafika, Jakarta, hlm. 2

3 Monika Suhayati, 2014, Perlindungan Hukum Terhadap Hak Ekonomi Pemilik Hak Terkait Dalam Undang-Undang Nomor 24 Tahun 2014 Tentang Hak Cipta, Jurnal Ilmiah
Peraturan perundang-undangan yang berlaku diatur dalam Pasal 1 angka 1 Undang-Undang Nomor 28 Tahun 2008 tentang Hak Cipta yang mengatakan:

"Hak Cipta adalah hak eksklusif pencipta yang timbul secara otomatis berdasarkan prinsip deklaratif setelah suatu ciptaan diwujudkan dalam bentuk nyata tanpa mengurangi pembatasan sesuai dengan ketentuan peraturan perundang-undangan" Adanya hak atas hak cipta secara otomatis yang artinya ciptaan sudah dilahirkan atau adanya perwujudan dalam bentuk yang nyata yang memerlukan formalitas tertentu yaitu melalui pendaftaran karena merupakan suatu ciptaan sebagai hasil karya pencipta yang mengandung keaslian serta berada dalam lapangan ilmu pengetahuan, seni, dan sastra. Ciptaan yang dilindungi oleh hak cipta berdasarkan Pasal 40 (huruf d) Undang-Undang Nomor 28 Tahun 2014 tentang Hak Cipta yaitu lagu atau musik

Yang artinya adalah ciptaan yang utuh terdiri dari unsur lagu atau melodi, syair atau lirik, dan termasuk notasinya bahwa lagu atau musik merupakan satu kesatuan karya cipta. Pengertian dari pencipta lagu atau musik adalah seseorang atau beberapa orang yang secara bersama-sama menciptakan suatu ciptaan lagu berdasarkan

Hukum, Vol 5, No. 2 (2014), https://jurnal. dpr.go.id/index.php/hukum/article/view/241, diaskes pada tanggal 01 Oktober 2017 
inspirasinya ataupun kemampuannya pikiran yang dituangkan dalam bentuk khas dan bersifat pribadi. ${ }^{4}$

Pengguna lagu atau musik yang sering mendengarkan lagu-lagu ciptaan seseorang untuk tujuan komersial yang artinya lagu atau musik didengarkan kembali oleh ciptaan seseorang yang menguntungkan bagi dirinya misalnya hotel-hotel, diskotik-diskotik, restoranrestoran, radio dan televisi, karaoke dan sebagainya diwajibkan pembayaran royalti kepada pemegang hak cipta lagu tersebut. Royalti itu sendiri dapat diartikan sebagai kompensasi bagi penggunaan sebuah ciptaan termasuk karya cipta lagu.

Berdasarkan hal tersebut dalam penelitian ini dapat ditentukan rumusan masalah adalah bagaimana konsepsi pelaksanaan perlindungan bagi pencipta atau pemegang hak cipta dalam peraturan penarikan royalti bagi pelaku usaha komersial karaoke berdasarkan Nomor. 28 Tahun 2014 Tentang Hak Cipta? Dan bagaimana efektifitas pelaksanaan penegakan hukum dalam penarikan royalti bagi pelaku usaha komersial karaoke?

Penulisan karya ilmiah ini belum pernah diteliti sebelumnya. Adapun karya ilmiah yang terkait dengan karya ilmiah Penulis tentang implementasi pembayaran royalti bagi pelaku usaha komersial karaoke berdasarkan ketentuan Undang-Undang Nomor. 28 tahun 2014 tentang hak cipta

4 Hendratanu, Atmadja, 2003, Hak Cipta Musik atau Lagu, Penerbit Pasca Sarjana Universitas Indonesia, Jakarta, hlm. 55. yaitu karya ilmiah dari Faishal Rizki Pratama tahun 2016, Diponegoro Law Journal, dengan judul Pelaksanaan Pengumuman Karya Cipta Lagu Sebagai Background Music Di Pusat Perbelanjaan (Studi Pada Pasaraya Purwokerto)yangrumusanmasalahnya adalah; 1. Bagaimana pelaksanaan karya cipta lagu sebagai background music di pusat perbelanjaan rita purwokerto?: 2. Apa saja yang dihadapi dalam pelaksanaan pengumuman karya cipta lagu sebagai background music dipusat perbelanjaan?.Karya ilmiah lainnya yang terkait yaitu Rezky Lendi Maramis tahun 2014, Lex Privatum, dengan judul Perlindungan Hukum Hak Cipta Atas Karya Musik dan Lagu Dalam Hubungan Dengan Pembayaran Royalti yang rumusan masalahnya adalah; 1. Bagaimana perlindungan tentang hak cipta karya musik dan lagu?: 2. Bagaimana mekanisme pembayaran royalti atas hak cipta karya musik dan lagu?. Jelas nampak perbedaan dari karya ilmiah tersebut dengan karya ilmiah yang dibuat oleh Penulis.

Tujuan dari penelitian ini adalah untuk 1 memahami betapa pentingnya perlindungan hukum terhadap pencipta karya musik dan lagu termasuk cara memperoleh haknya (Royalti) berdasarkan Undang-Undang Nomor. 28 Tahun 2014 Tentang Hak Cipta 


\section{METODE PENELITIAN}

Dalam penulisan karya ilmiah ini menggunakan jenis penelitian hukum empiris. Penelitian hukum empiris adalah penelitian yang terletak pada kenyataan yang ada di lapangan dan di tengah-tengah masyarkat yang menyangkut hukum. ${ }^{5}$

Penelitian ini bersifat deskriptif yang artinya yang menunjukkan ada tidaknya gejala-gejala yang ada di masyarakatyangmengambarkansecara tepat sifat indvidu. Data penelitian yang digunakan yaitu data primer dari informan dan responden dan data sekunder dari kepustakaan. Teknik pengumpulan data menggunakan teknik studi dokumen dan teknik wawancara. Teknik pengolahan datanya dengan analisis kualitatif.

\section{HASIL DAN PEMBAHASAN} 3.1. Perlindungan Bagi Pencipta Atau Pemegang Hak Cipta Dalam Peraturan Penarikan Royalti Bagi Pelaku Usaha Komersial Karaoke Berdasarkan Undang-Undang No. 28 Tahun 2014 Tentang Hak Cipta.

Hak cipta berisikan hak ekonomi (economic right) dan hak moral (moral right). Hak ekonomi adalah hak untuk mendapatkan manfaat ekonomi atas Ciptaan serta produk hak terkait. Sedangkan hak moral adalah hak yang melekat pada diri Pencipta atau Pelaku yang tidak dapat dihilangkan

5 Amiruddin, H Zainal Asikin, 2008, Pengantar Metode Peneliian Hukum, PT. Raja Grafindo Persada, Jakarta, hlm.25 atau dihapus tanpa alasan apapun, walaupun Hak Cipta atau Hak Terkait telah dialihkan. Dari pengertian tersebut, jelas bahwa hak ekonomi dari hak cipta dapat beralih atau di alihkan kepada orang lain. Dengan demikian, yang dapat beralih atau dialihkan itu hanyalah hak ekonomi saja dari hak cipta, sementara hak moralnya tidak dapat dipisahkan dari diri penciptanya. ${ }^{6}$

Setiap suatu karya "lagu" yang tercipta sudah mempunyai suatu perlindunganhukumyaituperlindungan hak cipta, kejelasan hukum hubungan antara hasil karya cipta dengan pencipta atau pemegang hak cipta atau orang yang menggunakan ciptaan tersebut. Undang-Undang Hak Cipta Nomor 28 Tahun 2014 yang semakin memperjelas perlindungan hukum yang diberikan pemerintah untuk suatu karya cipta, khususnya di sini karya cipta musik dan lagu. Ciptaan yang dilindungi oleh Undang-Undang Hak Cipta Nomor 28 Tahun 2014 diatur dalam Pasal 40 ayat 1 huruf d. Undang-Undang Hak Cipta menjelaskan adanya kepastian hukum antara pencipta atau pemegang hak cipta dengan suatu ciptaan yang ada, memberikan perlindungan yang utuh kepada pemilik hak cipta. Jadi jika pelaku usaha komersial karaoke ingin menggunakan lagu dalam perusahaan karaoke mereka harus

6 Rezky Lendi Maramis, 2014, Perlindungan Hukum Hak Cipta Atas Karya Musik dan Lagu Dalam Hubungan Dengan Pembayaran Royalti, Lex Privatum, Vol.II/No. 2/April/ 2014https://ejournal.unsrat.ac.id/index. $\mathrm{php} /$ lexprivatum/article/view/4537, diakses tanggal 01 Oktober 2017. 
menggunakan prosedur yang sudah di tentukan dalam Undang-Undang Hak cipta 2014, seperti harus adanya pemberian lisensi dari pihak pencipta lagu kepada pengguna lagu, jangka waktu penggunaan dan berapa royalti yang harus diberikan oleh pengguna hak cipta kepada pemilik hak cipta.

Hak cipta merupakan salah satu cabang Hak Kekayaan Intelektual secara umum yang sudah diakui baik secara internasional maupun secara nasional. Hal ini dibuktikan dengan munculkan serta diberlakukannya konvensi-konvensi internasional maupun peraturan lainnya yang mengatur mengenai hak cipta. Beberapa aturan tersebut dapat dilihat dalam skala internasional muncul TRIPs (Agreement on Trade Related Aspects of Intellectual Property Rights) yang di dalamnya juga menyinggung mengenai masalah hak cipta. ${ }^{7}$ UndangUndang Republik Indonesia tentang Hak Cipta sudah mengalami beberapa perubahan berupaya penyempurnaan sejak diundangkan yaitu UU No. 6 Tahun 1982 tentang Hak Cipta, UU No. 7 Tahun 1987 tentang Hak Cipta, UU No. 12 Tahun 1997 tentang Hak Cipta, UU No. 19 Tahun 2002 tentang Hak Cipta dan sudah tidak sesuai lagi dengan perkembangan hukum dan kebutuhan masyarakat sehingga perlu diganti dengan Undang-Undang Hak Cipta yang baru.

Pertengahan tahun 2014, pemerintah telah mengeluarkan

7 Arif Lutviansori, 2010, Hak Cipta dan Perlindungan Folklor di Indonesia, Graha Ilmu, Yogyakarta, hlm. 9 pengaturan baru mengenai Hak Cipta dengan perubahan Undang-Undang Nomor 28 tahun 2014 Tentang Hak Cipta. Dalam Undang-Undang Hak Cipta ini ada salah satu klausul di pasal 87 ayat 1 disebutkan:

"Untuk mendapatkan hak ekonomi setiap pencipta, pemegang hak cipta, dan pemilik hak terkait yang menjadi anggota Lembaga Manajemen Kolektif (LMK) agar dapat menarik imbalan yang wajar dari pengguna yang memanfaatkan hak cipta dan hak cipta terkait dalam bentuk layanan publik yang bersifat komersial".

Yang artinya setiap pengguna hak ciptaan, hak cipta terkait seperti bisnis karaoke diwajibkan membayar royalti penggunaan hak cipta melalui Lembaga Manajemen Kolektif( LMK) atau Yayasan Karya Cipta Indonesia (YKCI).

Dalam ketentuan umum Pasal 1 angka 21 dan 22 UU No. 28 Tahun 2014 tentang Hak Cipta:

"Pasal 1 angka 21 pengertian Royalti adalah imbalan atas pemanfaatan hak Ekonomi suatu ciptaan atau produk hak terkait yang diterima oleh pencipta atau pemilik hak terkait".

"Pasal 1 angka 22 pengertian Lembaga Manajemen Kolektif (LMK) adalah institusi yang berbentuk badan hukum nirlaba yang diberi kuasa oleh pencipta, pemegang hak cipta, dan/ atau pemilik Hak terkait guna 
mengelola hak ekonominya dalam bentuk menghimpun dan mendistribusikan royalti”.

Satu hal yang harus dicermati apabila pihak lain ataupun pelaku usaha ingin menggunakan lagu untuk ditempat usahanya misalkan karaoke, sepatutnya meminta ijin kepada si pemilik atau pemegang hak cipta, karena satu hal yang harus di cermati adalah pembayaran royalti yang harus dibayarkan, karena lagu adalah suatu karya intelektual yang harus dilindungi hukum. Royalti yang dibayarkan akan langsung di distribusikan oleh KCI kepada para pencipta lagu yang karyanya telah di gunakan oleh pengguna ataupun pemakai seperti para pelaku usaha. Pengguna ataupun pemakai dapat juga memiliki lisensi dari KCI sehingga pemakai ataupun pengguna bisa menggunakan jutaan karya cipta musik untuk kepentingannya, tetapi adapun konsekuensinya yaitu harus membayar royalti kepada KCI atas lisensi tersebut.

Manfaat Lisensi KCI bagi pengguna adalah :

a. Ijin untuk memperdengarkan musik ataupun lagu untuk kenyamanan para konsumen untuk menambah nilai ekonomi bagi kegiatan pelaku usaha.

b. Menjamin para pelaku usaha dari segala tuntutan hukum.

c. Pembayaran royalti lagu di Indonesia dan asing lebih murah dibandingkan pembayaran royalti di negara-negara lain. d. Efisiensi biaya yang tidak perlu meminta ijin ataupun bernegosiasi lagi kepada para pencipta lagu secara satu persatu di seluruh Indonesia.

Dengan adanya pergantian Undang-Undang Hak ciptayang terbaru yaituUndang-Undang Nomor 28Tahun 2014 tentang Hak Cipta, semoga akan memberikan perlindungan hak cipta yang lebih ditingkatkan dari peraturan perundang-undangan sebelumnya. ${ }^{8}$

\subsection{Efektivitas Pelaksanaan \\ Penegakan Hukum Dalam Penarikan Royalti Bagi Pelaku Usaha Komersial Karaoke}

Peraturan perundang-undangan, baik yang tingkatnya lebih rendah maupunyanglebihtinggibertujuanagar masyarakat maupun aparatur penegak hukum dapat melaksanakan secara konsisten dan tanpa membedakan antara masyarakat yang satu dengan masyarakat yang lainnya. ${ }^{9}$ Apabila undang-undang itu dilaksanakan dengan baik, maka undang-undang itu dikatakan efektif, karena bunyi undang-undangnya jelas dan tidak perlu adanya penafsiran, aparatnya menegakkan hukum secara konsisten dan masyarakat yang terkena aturan tersebut sangat mendukungnya.

8 Faishal Rizki Pratama, 2016, Pelaksanaan Pengumuman Karya Cipta Lagu Sebagai Background Music Di Pusat Perbelanjaan (Studi Pada Rita Pasaraya Purwokerto), Diponegoro Law Journal, Vol 5, No. 4 (2016), http://ejournal-s1.undip.ac.id/index.php/dlr/ article/view/13585, diakses pada tanggal 01 Oktober 2017.

9 H. Salim HS dan Erlies Septiana Nurbani, op.cit., 2014, hlm. 301 
Berdasarkan wawancara dengan Bapak Triyono, SH., Penyidik Pegawai Negeri Sipil Pada Kementrian Hukum dan HAM RI Kanwil Jatim di Surabaya, menjelaskan bahwa penegakan hukum adalah penjelasan Undang-Undang di dalam prakteknya menurut Bapak Triyono, SH untuk penegakan hukum dalam penarikan royalti bagi komersial karaoke belum begitu efektif karena masih banyak aspeknya tentang penetapan besaran royalty yang sepihak yang tidak menjamin kepastian hukum dan mengindahkan rasa keadilan dan tidak adanya mekanisme pengawasan dalam pelaksanaan penarikan royalti apakah benar untuk kepentingan perlindungan bagi pencipta atau pemegang hak cipta atau untuk kepentingan lembaga yang memang sah namun royaltinya tidak ada mengawasinya.

Delik aduan yang dimiliki dari Yayasan Karya Cipta Indonesia (YKCI) membuat semakin penegakan hukum perkaranya dalam karya cipta semakin lambat, dikarenakan penegakan hukumnya semakin pasif, bekerjanyaberdasarkanaduan sajayang dirugikan. Sedangkan banyak pencipta yang dirugikan tetapi malas untuk pengaduan karena prosesnya yang panjang dan beberapa faktor seperti sarana atau fasilitas yang mempunyai peran penting dalam penegakan hukum. Tanpa adanya sarana atau fasilitas tersebut tidak akan mungkin penegak hukum menyerasikan peranan yang seharusnya dengan peranan yang aktual.

\section{KESIMPULAN}

Substansi peraturan perundangundangan hak cipta, sudah secara jelas mengatur tentang perlindungan hak cipta mengenai lagu dan/atau musik diatur dalam pasal 40 ayat 1 huruf $d$ dan pengaturan tentang pembayaran royalti setiap pengguna hak ciptaan, hak cipta terkait seperti bisnis karaoke diwajibkan membayar royalti penggunaan hak cipta melalui Lembaga Manajemen Kolektif( LMK) atau Yayasan Karya Cipta Indonesia (YKCI).

Efektivitas penegakan hukum pembayaran royalti pelaku usaha komersial karaoke belum efektif karena masih banyak aspeknya tentang penetapan besaran royalti yang sepihak yang tidak menjamin kepastian hukum dan mengindahkan rasa keadilan.

\section{DAFTAR PUSTAKA}

\section{BUKU}

Ali, A. (2009). Menguak teori hukum (legal theory) dan teori peradilan (judicialprudence) termasuk interpretasi undang-undang (legisprudence). Jakarta: Kencana.

Ali, Z. (2009). Metode Penelitian Hukum. Sinar Grafika. Jakarta.

Amiruddin, H. Zainal Asikin, 2012, Pengantar Metode Penelitian Hukum, Cetakan ke-6, Edisi Pertama, Penerbit: PT. Raja Grafindo Persada, Jakarta. 
Atmadja, H. T. (2003). Hak Cipta Musik atau Lagu, Penerbit Pasca Sarjana Universitas Indonesia, Jakarta.

Ermansyah, D. (2009). Hukum Hak Kekayaan Intelektual. Sinar Grafika. Jakarta.

Fuady, M. (2004). Hukum dagang internasional (aspek hukum dari WTO). Citra Aditya Bakti. Bandung.

Gunawan, W. (2001). Seri Hukum Bisnis Lisensi. RajaGrafindo Persada, Jakarta.

Gunawan, A. (2002). Kamus Praktis Ilmiah Populer. Surabaya: Kartika.

Lutviansori, A. (2010). Hak cipta dan perlindungan folklor di Indonesia: dilengkapi dengan Berne Convention for the Protection of Literary and Artistic Works. Graha Ilmu.

Manan, A. (2005). Aspek-aspek pengubah hukum. Kencana. Jakarta.

Marzuki, P. M. (2011). Penelitian Hukum, Jakarta: Kencana. Mertokusumo, Sudikno.

Muhammad, A. (2001). Kajian Hukum Ekonomi Hak Kekayaan Intelektual. Citra Aditya Bakti. Bandung

Muhammad, A. (2004). Hukum dan penelitian hukum. Citra Aditya Bakti, Bandung.

Rahayu, D. P. (2014). Budaya hukum Pancasila. Thafa Media. Yogyakarta.

Salim, H. S., \& Nurbani, E. S. (2014). Penerapan Teori Hukum Pada
Penelitian Disertasi dan Tesis. PT Raja Grafindo Persada, Jakarta.

\section{ARTIKEL JURNAL}

Maramis, R. L. (2014). Perlindungan Hukum Hak Cipta Atas Karya Musik Dan Lagu Dalam Hubungan Dengan Pembayaran Royalti. LEX PRIVATUM, 2(2).

Pratama, F. R., Susilowati, E., \& Mahmudah, S. (2016). PELAKSANAAN PENGUMUMAN KARYA CIPTA LAGU SEBAGAI BACKGROUND MUSIC DI PUSAT PERBELANJAAN (STUDI PADA RITA PASARAYAPURWOKERTO). Diponegoro Law Journal, 5(4), 1-17.

Suhayati, M.(2016).PELINDUNGAN HUKUM TERHADAP HAK EKONOMI PEMILIK HAK TERKAIT DALAM UNDANGUNDANG NOMOR 28 TAHUN 2014 TENTANG HAK CIPTA (LEGAL PROTECTION FOR THE OF ECONOMIC RIGHTS OF THE RELATED RIGHTS'OWNER IN LAW NUMBER 28 OF 2014 ON COPYRIGHT). Negara Hukum, 5(2), 207-221.

\section{PERATURAN}

\section{PERUNDANG-UNDANGAN}

Undang-Undang Nomor 28 Tahun 2014 Tentang Hak Cipta. 